\title{
IMPLEMENTASI SENSOR MQ-2 SEBAGAI ALAT DETEKSI ASAP ROKOK MENGGUNAKAN ATMEGA328
}

\section{Arif Setia Sandi A. ${ }^{\bowtie}$, Imam Ahmad Ashari, Retno Agus Setiawan, R. Bagus Bambang Sumantri}

Fakultas Sains dan Teknologi, Universitas Harapan Bangsa, Banyumas, Indonesia Email: arifsetia@uhb.ac.id

DOI: https://doi.org/10.46880/jmika.Vol5No2.pp110-115

\begin{abstract}
Smoking is an activity that can make addiction a habit every day, because cigarettes contain substances that are harmful to the user's body and to other people who inhale the smoke. Included in the school environment, several factors that increase interest in cigarettes among students are the factor of wanting to try, being influenced by friends and the environment. The school environment has a big impact, with rules and regulations that are not enforced to the maximum resulting in an increasing number of cigarette users among students. this can affect the friends around him. From these problems, the authors conducted research using Arduino Uno as the main component in the development of the Cigarette Smoke Detection Tool which was combined with the MQ-2 sensor as a module used for cigarette smoke detection, and the module will sound a buzzer when it detects cigarette smoke, then combined with the module. GSM as a tool to notify a predetermined number when cigarette smoke is detected in the room via SMS (Short Message Service). The result of this test is that the MQ-2 sensor can detect if there is cigarette smoke around the sensor or device at a short distance of less than 6 meters.
\end{abstract}

Keyword: MQ2, Arduino, Atmega328, Smoke.

\begin{abstract}
ABSTRAK
Merokok merupakan aktifitas yang dapat menjadikan kecanduan hinigga kebiasaan setiap hari, karena didalam rokok terdapat kandungan-kandungan yang berbahaya bagi tubuh pengguna maupun bagi orang lain yang menghisap asap rokok tersebut. Termasuk dalam lingkungan sekolah, beberapa faktor yang membuat peminat rokok dikalangan pelajar meningkat adalah faktor ingin mencoba, terpengaruh teman maupun lingkungan. Lingkungan sekolah memiliki dampak yang besar, dengan tata tertib dan peraturan yang tidak ditegakkan dengan maksimal mengakibatkan pengguna rokok dikalangan pelajar semakin meningkat. hal ini dapat mempengaruhi teman disekitarnya. Dari masalah tersebut, penulis melakukan penelitian menggunakan Arduino Uno sebagai komponen utama dalam pengembangan Alat Deteksi Asap Rokok yang digabungkan dengan sensor MQ-2 sebagai modul yang digunakan untuk deteksi asap rokok, dan modul tersebut akan membunyikan buzzer apabila mendeteksi asap rokok, kemudian digabungkan dengan modul GSM sebagai alat untuk memberitahu kepada nomor yang telah ditentukan apabila terdeteksi asap rokok pada ruangan tersebut melalui SMS (Short Message Service). Hasil dari pengujian ini adalah sensor MQ-2 dapat mendeteksi apabila terdapat asap rokok disekitar sensor atau alat dalam jarak dekat kurang dari 6 meter.
\end{abstract}

Kata Kunci: MQ2, Arduini, Atmega328, Asap.

\section{PENDAHULUAN}

Semakin meningkatnya konsumen rokok berdampak terhadap jumlah peminat rokok diusia remaja hingga anak-anak yang semakin besar. Beberapa faktor yang membuat peminat rokok dikalangan anak dibawah umur meningkat adalah faktor ingin mencoba, terpengaruh teman maupun lingkungan. Lingkungan sekolah menjadi salah satu yang memiliki berdampak besar, tata tertib dan peraturan yang tidak ditegakkan dengan maksimal mengakibatkan pengguna rokok dikalangan pelajar semakin meningkat. hal ini dapat mempengaruhi teman disekitarnya. Untuk mengatasi masalah tersebut perlu adanya perbaikan pada sistem pemantauan aktifitas pelajar, terutama sistem pendeteksi apabila terdapat pelajar yang merokok dilingkungan sekolah, termasuk dalam ruang pembelajaran.

Dari masalah tersebut, penulis merancang aplikasi untuk mempermudah deteksi aktivitas merokok didalam ruang pembelajaran melalui asap rokok tersebut. Dengan adanya peningkatan sistem diharapkan mampu menyelesaikan masalah dalam 
mengurangi kemungkinan pelajar yang merokok didalam ruang pembelajaran.

Beberapa penelitian yang sudah pernah dilakukan oleh peneliti lain diantaranya perancangan sistem penyegaran ruangan dari asap rokok berbasis mikrokontroler ATMega8535 (Akhwandi \& Yudhana, 2017) dan rancang bangun detektor asap rokok menggunakan SMS Gateway untuk Asrama Crystal di Universitas Klabat (Sujatmoko, Waworundeng, \& Wahyudi, 2015).

\section{KAJIAN LITERATUR Merokok}

Berdasarkan penelitian yang dilakukan oleh Sutha (2018) dengan judul "Pengetahuan dan Perilaku Merokok Pelajar Sekolah Menengah Pertama” mengungapkan bahwa perokok di usia remaja khususnya anak sekolah sering terjadi pada siswa pria, hal ini dibuktikan dari karakteristik subjek penelitiannya berdasar dari usia, mayoritas responden berusia 14 tahun yaitu kisaran 20,9\% dan responden dengan jenis kelamin laki-laki yaitu sebanyak 52,4\%, semua responden berstatus sebagai pelajar sekolah menengah pertama negeri yang berada di Kecamatan Sampang (Sutha, 2018).

Penelitian lainnya dengan judul "Perilaku Merokok di Kalangan Siswa Sekolah Menengah Atas di Kota Padang" menggunakan metode statistika menunjukan bahwa teman seumuran akan memiliki nilai pengaruh yang sangat besar, dibuktikan berdasarkan statistik sebagian besar siswa memiliki teman dengan perilaku yang kurang baik (merokok) dan terdapat relasi yang signifikan antara faktor teman seumuran yang merokok dengan perilaku merokok pada siswa sekolah menengah atas di Kota Padang dengan resiko 10 kali lebih besar (Sari, 2019).

Sulastri, dkk (2018) pada penelitian yang berjudul "Keinginan Berhenti Merokok Pada Pelajar Perokok Berdasarkan Global Youth Tobacco Survey di SMK Negeri Kota Padang" menunjukan bahwa bahwa mayoritas pelajar yang merokok berkeinginan untuk berhenti merokok, diantaranya pernah mencoba berhenti merokok dalam 12 bulan terakhir, mayoritas pelajar perokok menyadari jika dirinya memiliki tekad dan kemauan untuk mulai berhenti merokok, sebagian besar pernah mendapatkan nasehat dari teman maupun keluarga atau program berhenti merokok dari ahli (Herman \& Darwin, 2018).

ATMega328

Mikrokontroler Arduino merupakan seperangkat elektronik atau papan rangkaian elektronik yang tersusun dan bersifat terbuka untuk dapat dilakukan modifikasi sesuai tujuan yang diinginkan (Istiyanto, 2014). Komponen utama arduino berupa komponen kecil mikrokontroler dengan jenis AVR dari perusahaan Atmel yang telah banyak digunakan dalam berbagai implementasi (Andrianto, 2015).

Mikrokontroler arduino memiliki banyak jenis dan salah satu jenis mikrokontroler arduino yang digunakan pada penelitian ini adalah Mikrokontroler Arduino Uno R3. Arduino jenis ini merupakan sebuah board mikrokontroler yang berbasis ATmega328, mudah dihubungkan ke sebuah komputer dengan sebuah kabel USB atau mensuplainya dengan sebuah adaptor AC ke DC atau menggunakan baterai untuk memulainya (Sujatmoko et al., 2015).

\section{Sensor MQ-2}

Sensor MQ-2 merupakan modul yang dipakai untuk mendeteksi konsentrasi gas yang sifatnya mudah terbakar. Sensor MQ-2 memungkinkan untuk langsung diatur sensitivitasnya dengan memutar trimpot yang terdapat pada modul sensornya. Sensor MQ-2 sering digunakan sebagai modul deteksi kebocoran gas dalam ruangan. Gas yang dapat dideteksi diantaranya: Gas LPG, i-butane, propane, methane, alcohol, hydrogen, dan smoke (Sarmidi \& Akhmad Fauzi, 2019).

\section{Modul SIM800L}

Modul SIM800L merupakan modul SIM yang mempunyai fungsi sebagai alat komunikasi dan berfungsi sebagai pengirim informasi kepada pemantau utama dengan perangkat seluler. AT-Command merupakan salah satu perintah yang terdapat pada modem GSM/CDMA dengan fungsi untuk mengirim dan menerima data berbasis GSM/GPRS. SIM800L GSM/GPRS dikendalikan melalui perintah AT. AT+Command adalah sebuah kumpulan perintah yang digabungkan dengan karakter lain setelah karakter "AT" yang biasanya digunakan pada komunikasi serial (Rahajeng, Wahyuni, \& Irawan, 2020).

\section{METODE PENELITIAN}

\section{Flowchart Alat}

Berikut ini adalah flowchart alat deteksi asap rokok menggunakan mikrokontroler atmega328 berbasis sms sebagai media informasi 


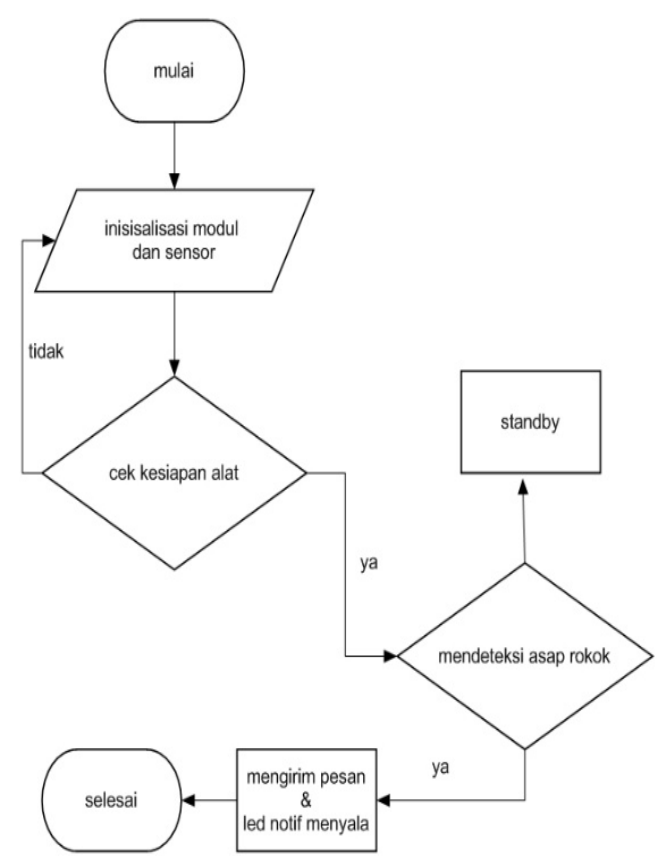

Gambar 1. Flowchart Alat Deteksi Asap Rokok Menggunakan Mikrokontroler ATMega328 berbasis SMS Sebagai Media Informasi

\section{Analisa Kebutuhan Hardware}

Perangkat keras yang dimaksud adalah komponen-komponen elektronika yang dipakai dalam rancangan alat ini. Minimal dari kebutuhan perangkat keras (hardware) untuk pembuatan alat ini adalah:

- Mikrokontroler ATMega328 (Arduino Uno)

- Sensor MQ-2

- Modul Step Down LM2596 Converter

- Modul GSM SIM800L

- Baterai/ Powerbank

- Handphone

- Casing/ Box

- LED

\section{Analisa Kebutuhan Software}

Perangkat lunak yang dimaksud yaitu berupa aplikasi yang akan dipakai oleh pengguna untuk menjalankan instruksi-instruksi pengendalian dan mengkoordinasikan kegiatan dalam sistem komputer. perangkat lunak (software) minimum yang diperlukan dalam pembuatan alat ini antara lain:

- Windows 7 64bit OS

- IDE Arduino

- Google Skecthup

- Fritz

\section{Perancangan Sistem}

Berikut ini merupakan bagan perancangan sistem yang dibuat oleh peneliti:

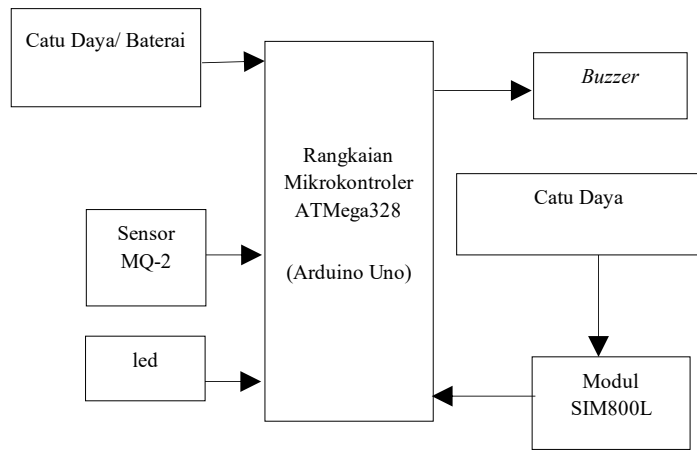

Gambar 2. Diagram Blok Rangkaian Alat

Gambar di atas dapat dijelaskan bahwa alat pendeteksi asap rokok yang dirancang tersebut menggunakan alat masukan (input), proses dan keluaran (output) dengan detail fungsi sebagai berikut:

\section{Input}

Komponen input yang dibahas disini merupakan komponen perangkat masukan yang dapat berfungsi juga sebagai komponen pendukung dari rangkaian. Komponennya terdiri dari:

a. Catu Daya yang berfungsi sebagai suplai daya pada rangkaian pendeteksi. Catu daya untuk rangkaian Modul GSM SIM800L dan rangkaian arduino dengan modul lain dibuat terpisah karena Modul GSM SIM800L memerlukan supply daya yang stabil. Pada kasus ini digunakan baterai berkapasitas 9v.

b. Sensor MQ-2 yang berfungsi untuk mendeteksi adanya gas dan asap pada rokok. Sensor ini juga dapat digunakan untuk mendeteksi berbagai asap, tidak hanya asap yang terdapat pada rokok.

\section{Proses}

Proses menjadi bagian inti dari sebuah rangkaian dimana semua masukan akan melalui tahapan ini untuk menghasilkan sebuah output. Dalam proses in menggunakan Mikrokontroler ATMega328 (Arduino Uno) yang berfungsi untuk menjalankan program secara keseluruhan, komponen yang termasuk terdiri dari:

a. Mikroprosesor ATMega328 (yang terdapat pada Arduino Uno)

b. Modul GSM SIM800L

c. Modul Step Down Converter 


\section{Output}

Komponen output merupakan komponen perangkat luaran yang dapat berfungsi juga sebagai komponen pendukung dari rangkaian. Komponen output terdiri dari:

a. Buzzer berfungsi sebagai notifikasi berupa suara pada saat pertama kali sensor MQ-2 mendeteksi adanya zat yang terdapat pada asap rokok. Notifikasi suara ini ditujukan sebagai peringatan terhadap orang disekitar bahwa terdapat asap rokok atau orang yang sedang merokok disekitar lokasi alat tersebut diletakkan.

b. SMS, Setelah output berupa buzzer berbunyi. Kepala laboratorium komputer sebagai penanggung jawab ruangan akan menerima notifikasi berupa SMS bahwa didalam laboratorium komputer terdapat asap rokok atau ada orang merokok disekitar.

\section{HASIL DAN PEMBAHASAN}

\section{Desain dan Perakitan Alat}

Perancangan modul elektronik dengan menggunakan Baterai 9v sebagai sumber daya untuk modul SIM800L melalui perantara step-down converter sebagai penurun daya dari $9 \mathrm{~V}$ ke $4.2 \mathrm{~V}$ (Syahwil, 2013).

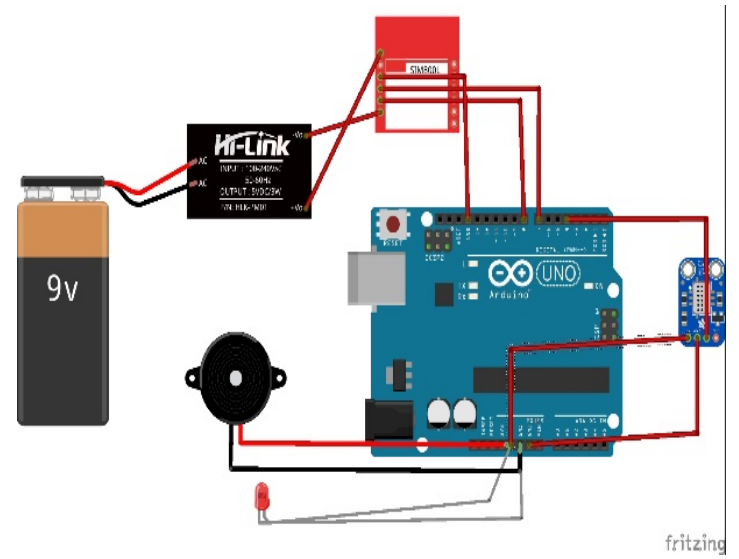

Gambar 3. Diagram Wiring

Perancangan desain alat dibuat menggunakan aplikasi Google Sketchup yang mempunyai fungsi sebagai aplikasi desain tiga dimensi yang umumnya dipakai di bidang teknik sipil, arsitektur, dalam pembuatan game, film, dan rancangan yang terkait dunia tiga dimensi.

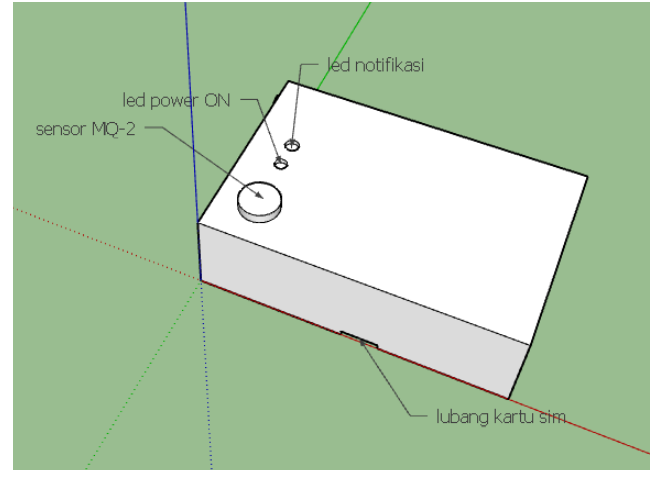

Gambar 4. Desain Alat Tampat Depan

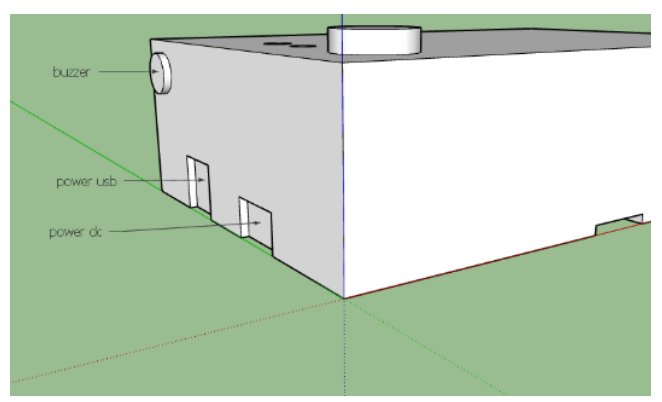

Gambar 5. Desain Alat Tampak Atas

Tahap awal pembuatan rangkaian alat ini adalah dengan memasang modul GSM SIM800L ke rangkaian modul Step Down dan Mikrokontroler ATMega328 (Arduino Uno) yang digambarkan pada skema dibawah ini :

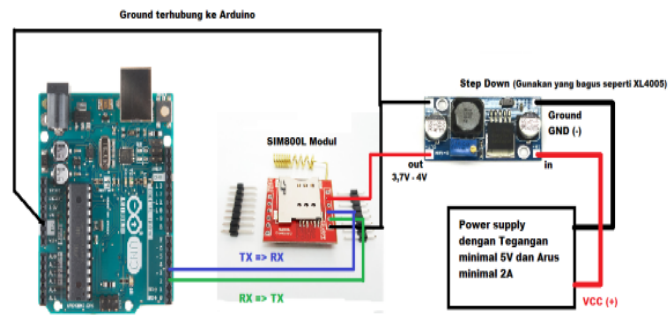

Gambar 6. Skema Rangkaian 1

\section{Implementasi Kode Program}

Menuliskan program ke software IDE Arduino. file ini akan ber-ekstensi “.ino”. Setelah program disimpan dalam ekstensi (.ino), 113ompute selanjutnya adalah mengecek program yang telah dibuat dengan menghubungkan rangkaian Arduino dengan perangkat 113omputer yang digunakan untuk unggah kode program di software Arduino. 
V.r.

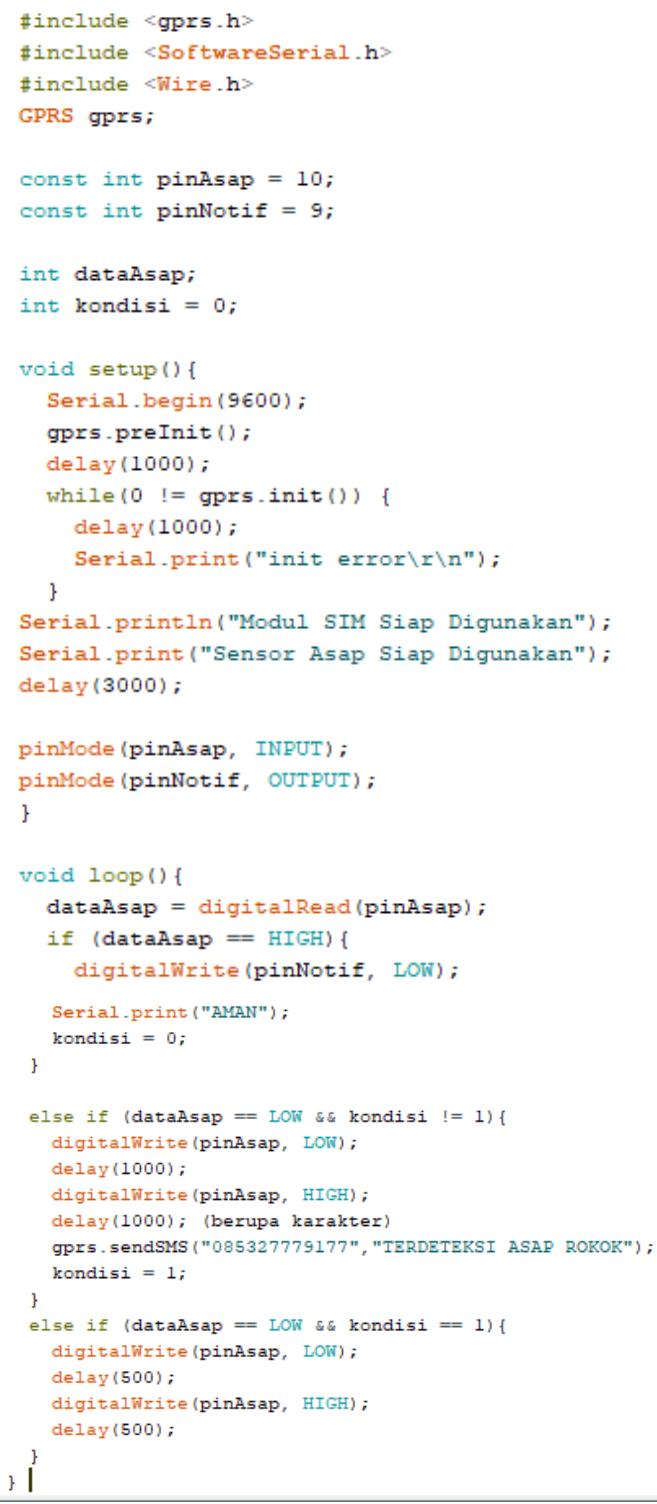

\section{Gambar 7. Kode Program}

Kemudian setelah modul GSM SIM800L terpasang tahap selanjutnya adalah memasang sensor MQ-2, Buzzer dan LCD 16x2 I2c ke rangkaian Mikrokontroler ATMega328 (Arduino Uno) dengan skema sebagai berikut:

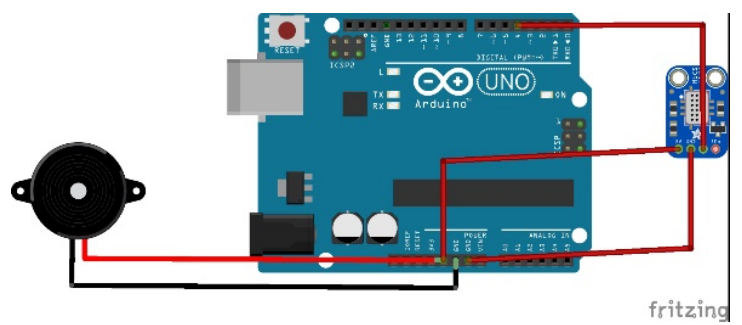

Gambar 8. Skema Rangkaian 2

Semua komponen, modul dan sensor dipasang kedalam box agar lebih rapi dan teratur.

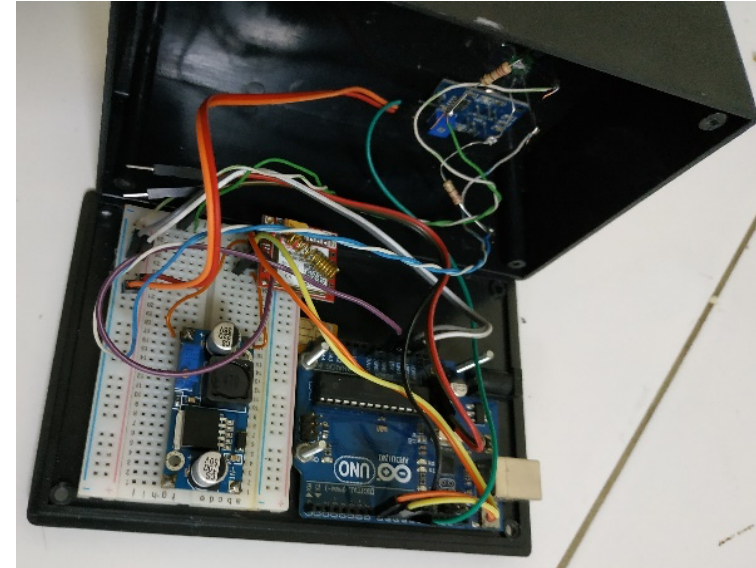

Gambar 9. Implementasi Rangkaian

\section{Pengujian}

Pengujian dilakukan dengan menyalakan sebatang rokok untuk menghasilkan asap, dan alat diharapkan akan mendeteksi adanya asap rokok disekitar alat tersebut, dibuktikan dengan pengiriman sms melalui modul SIM800L kepada nomor telepon yang telah diatur pada kode program.

Tabel 1. Pengujian Alat

\begin{tabular}{|c|c|c|c|}
\hline $\begin{array}{l}\text { Status } \\
\text { Kirim }\end{array}$ & Tampila & & Ket. \\
\hline $\mathrm{Ya}$ & 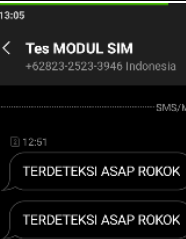 & $\begin{array}{l}30 \\
6 \quad 8 \\
6\end{array}$ & $\begin{array}{l}\text { Tampilan } \\
\text { sms ketika } \\
\text { terdeteksi } \\
\text { adanya } \\
\text { asap gas } \\
\text { rokok }\end{array}$ \\
\hline
\end{tabular}

\section{KESIMPULAN}

Hasil yang didapatkan dari perancangan serta pembuatan alat yang telah dilakukan, penulis menarik beberapa kesimpulan berdasarkan realisasi yang telah dilakukan. diantaranya:

1. Berhasil dirangkai perangkat Alat Deteksi Asap Rokok Menggunakan Mikrokontroler ATMega328 berbasis SMS Sebagai Media Informasi yang bekerja secara otomatis.

2. Pencegahan penggunaan rokok didalam ruangan lebih terkontrol dengan baik.

3. Sensor MQ-2 akan mendeteksi apabila terdapat asap rokok disekitar sensor atau alat dalam jarak kurang dari 6 meter. 


\section{DAFTAR PUSTAKA}

Akhwandi, D., \& Yudhana, A. (2017). SISTEM PENYEGARAN RUANGAN DARI ASAP ROKOK DAN GAS LPG BERBASIS MIKROKONTROLER ATMEGA 8535. Jurnal Ilmu Teknik Elektro Komputer Dan Informatika (JITEKI), 3(1), 27-35.

Andrianto, H. (2015). Pemrograman Mikrokontroler AVR ATmegal6 Menggunakan Bahasa C (CodeVisionAVR) revisi kedua. Bandung: Informatika Bandung.

Herman, D., \& Darwin, E. (2018). Artikel Penelitian Keinginan Berhenti Merokok Pada Pelajar Perokok Berdasarkan Global Youth Tobacco Survey di SMK Negeri Kota Padang. 7(2), 205211.

Istiyanto, J. E. (2014). Pengantar Elektronika \& Instrumentasi (Pendekatan Project Arduino \& Android). Yogyakarta: Andi Offset.

Rahajeng, A. S., Wahyuni, R., \& Irawan, Y. (2020). SISTEM KEAMANAN SEPEDA MOTOR MENGGUNAKAN. 90-100.

Sari, A. (2019). Perilaku Merokok di Kalangan Siswa Sekolah Menengah Atas di Kota Padang Smoking Behavior among High School Students in Padang City. Jurnal Ilmiah Kesehatan Masyarakat, 11, 238-244.

Sarmidi, \& Akhmad Fauzi, R. (2019). Pendeteksi Kebocoran Gas Menggunakan Sensor Mq-2 Berbasis Arduino Uno. Manajemen Dan Teknik Informatika, 03(01), 51-60.

Sujatmoko, A. S. R., Waworundeng, J., \& Wahyudi, A. K. (2015). Rancang Bangun Detektor Asap Rokok Menggunakan SMS Gateway Untuk Asrama Crystal di Universitas Klabat.

Proceedings Konferensi Nasional Sistem Dan Informatika (KNS\&I), 460-465. Bali: STIKOM.

Sutha, diah wijayanti. (2018). Pengetahuan dan Perilaku Merokok Pelajar Sekolah Menengah Pertama Knowledge and Smoking Behavior of Junior High School Student. Jurnal Manajemen Kesehatan, 4(1), 47-60.

Syahwil, M. (2013). Panduan Mudah Simulasi \& Praktek Mikrokontroler Arduino. Yogyakarta: Andi Offset. 